\title{
FAKTOR-FAKTOR YANG MEMPENGARUHI PERILAKU KONSUMEN DALAM PENGAMBILAN KEPUTUSAN UNTUK MEMILIH BERBELANJA DI HOME SMART
}

\author{
Ispantari Ramayanti ${ }^{1}$, Hayanuddin Safri ${ }^{2}$ \\ ${ }^{1}$ Alumni Sarjana Ekonomi STIE Labuhanbatu \\ ${ }^{2}$ Dosen STIE Labuhanbatu
}

\begin{abstract}
ABSTRAK
Tujuan dari penelitian ini adalah untuk mengetahui pengaruh faktor budaya, pribadi, sosial, dan psikologis terhadap keputusan konsumen untuk berbelanja di Home Smart, baik secara parsial maupun simultan. Penelitian ini menggunakan 96 responden sebagai sampel penelitian yang diambil dengan menggunakan teknik accidental sampling. Hasil penelitian berdasarkan uji secara serempak (uji F) menunjukkan bahwa secara simultan (serempak) faktor budaya, pribadi, sosial, dan psikologis berpengaruh positif dan signifikan terhadap keputusan konsumen untuk berbelanja di Home Smart. Hasil pengujian hipotesis secara parsial (uji t) menunjukkan bahwa faktor budaya, pribadi, sosial, dan psikologis secara parsial berpengaruh positif dan signifikan terhadap keputusan konsumen untuk berbelanja di Home Smart. Berdasarkan hasil uji determinasi diketahui bahwa keputusan konsumen dapat dijelaskan oleh faktor budaya, pribadi, sosial, dan psikologis sebesar 50,3\%, sedangkan sisanya 49,7\% dijelaskan oleh variabel lain yang tidak diteliti dalam penelitian ini, misalnya : merek, image, harga, promosi, dan lain sebagainya.
\end{abstract}

\section{Kata kunci : Faktor budaya, Pribadi, Sosial, Psikologis, Keputusan Konsumen.}

\section{Pendahuluan}

Berdasarkan hasil survei yang dilakukan oleh Nielsen, ternyata $85 \%$ pembelanja di ritel modern Indonesia cenderung untuk berbelanja sesuatu yang tidak direncanakan. Sebesar $61 \%$ konsumen biasanya memang merencanakan membeli sesuatu sehingga mereka datang ke ritel. Namun demikian, mereka kadang-kadang juga membeli sesuatu yang lain. Artinya mereka juga melakukan pembelian yang tidak direncanakan. Sebanyak 13\% konsumen selalu membeli yang lain, dan bahkan $10 \%$ benar-benar tidak merencanakan untuk membeli (Rosidi, Purwaningsih, dkk, 2010:2-3).

Pembelian harus mempunyai dasar pertimbangan yang masuk akal.
Sistem penjualan dengan swalayan dan tata ruang terbuka menimbulkan situasi pemasaran dimana konsumen menjadi lebih tertarik pada produk dikarenakan bagaimana produk tersebut dipajang (Setiadi, 2008:356). Diperlukan kreasi dan inovasi terus menerus agar konsumen tidak mudah bosan dengan produk yang ditawarkan. Dilihat dari kecenderungannya kebanyakan konsumen memilih jenis produk tertentu berdasarkan variasi produk dan merek yang sudah dikenal luas dipasaran. Kecenderungan seperti inilah yang harus diperhatikan oleh pemasar agar tidak kalah saing dengan merek lain yang produknya sejenis. Selera konsumen yang terus berubah menuntut pemasar mengenal konsumennya. Di kehidupan 
yang relatif konsumtif seperti saat ini dan gencarnya iklan serta jenis promosi lainnya, pemahaman tentang perilaku konsumen akan membantu pemasar mengetahui bagaimana motif, sikap maupun perilaku serta faktor-faktor usaha pemasaran maupun lingkungan eksternal lain yang dapat mempengaruhi pengambilan keputusan pembelian oleh konsumen.

Perilaku konsumen itu sendiri dipengaruhi oleh faktor budaya, sosial, pribadi, psikologis (Kotler 2007:214). Dalam hal pemasaran masih sulit untuk menentukan faktor apakah yang lebih dominan yang mempengaruhi konsumen dalam hal keputusan pembelian. Ada kalanya faktor sosial lebih dominan dibanding faktor lainnya dalam hal pembelian barang mewah. Tetapi ada kalanya juga faktor psikologis lebih dominan dari faktor lainnya dalam hal pembelian produk yang di beli tanpa perencanaan sebelumnya. Keputusan pembelian merupakan tahap dalam proses pengambilan keputusan pembeli dimana konsumen benar-benar membeli produk. Apapun faktor yang mempengaruhi konsumen dalam hal keputusan pembelian, berarti faktor tersebut memiliki perannya masing-masing dalam mempengaruhi perilaku konsumen.

Diperlukan pemahaman tentang perilaku konsumen agar pemasar mampu mengambil keputusan-keputusan pemasaran secara tepat. Dengan memahami perilaku konsumen diharapkan perusahaan mampu menemukan peluang-peluang apa saja yang belum terbaca oleh perusahaan lain yang dibutuhkan oleh konsumen. Pemahaman terhadap perilaku konsumen ini sangat bermanfaat untuk kepentingan penyusunan strategi maupun bauran pemasaran. Melalui pemahaman terhadap psikografis konsumen dan juga perilaku penggunaan, pemasar dapat melakukan segmentasi pasar, menyusun strategi promosi khususnya iklan secara tepat.

Home Smart merupakan salah satu supermarket yang ada di Kota Rantauprapat. Supermarket ini khusus menjual produk bahan bangunan dan perlatan rumah tangga sehingga pada umumnya masyarakat lebih mengenal supermarket ini dengan istilah "supermarket bangunan". Home Smart menyediakan semua kebutuhan bahan bangunan hingga barang elektronik dengan berbagai varian merek produk.

\section{Tinjauan Pustaka}

Menurut The American Marketing Assosiation (Setiadi 2008:3), perilaku konsumen merupakan interaksi dinamis antara afeksi dan kognisi, perilaku, dan lingkungannya dimana manusia melakukan kegiatan pertukaran dalam hidup mereka.

Menurut Kotler (2007:214) faktorfaktor yang mempengaruhi perilaku konsumen adalah budaya, sosial, pribadi, psikologis. Faktor-faktor tersebut harus diperhitungkan untuk mengetahui seberapa jauh dapat mempengaruhi pembelian konsumen.

\section{Faktor budaya}

Menurut Sumarwan (2007:170) budaya adalah segala nilai, pemikiran, simbol yang mempengaruhi perilaku, sikap, kepercayaan dan kebiasaan seseorang dan masyarakat. Adapun unsurunsur budaya antara lain :

1) Nilai

Nilai adalah kepercayaan atau segala sesuatu yang dianggap penting oleh seseorang atau suatu masyarakat.

2) Kebiasaan 
Kebiasaan adalah berbagai bentuk perilaku dan tindakan yang diterima secara budaya.

\section{Faktor sosial}

Menurut Rudito sosial adalah segala sesuatu yang dipakai sebagai acuan dalam berinteraksi antar manusia dalam konteks masyarakat atau komuniti, sebagai acuan berarti sosial bersifat abstrak yang berisi simbol-simbol berkaitan dengan pemahaman terhadap lingkungan, dan berfungsi untuk mengatur tindakan-tindakan yang dimunculkan oleh individu-individu sebagai anggota suatu masyarakat.

1) Kelompok acuan

Kelompok acuan seseorang terdiri dari semua kelompok yang memiliki pengaruh langsung (tatap muka) atau tidak langsung terhadap sikap atau perilaku seseorang. Kelompok yang memiliki pengaruh langsung terhadap seseorang dinamakan kelompok keanggotaan (Kotler, 2007:216). Beberapa merupakan kelompok primer yang mempunyai interaksi reguler tapi informal seperti keluarga, teman, tetangga dan rekan kerja. Beberapa merupakan kelompok sekunder, yang mempunyai interaksi secara formal dan kurang reguler, contohnya adalah organisasi.

2) Keluarga

Keluarga adalah organisasi pembelian konsumen yang paling penting dalam masyarakat dan para anggota keluarga menjadi kelompok acuan primer yang paling berpengaruh.

3) Peran dan Status

Posisi seseorang dalam tiap-tiap kelompok dapat didefinisikan dalam peran dan status. Peran meliputi kegiatan yang diharapkan akan dilakukan oleh seseorang. Setiap peran membawa status yang mencerminkan penghargaan umum yang diberikan oleh masyarakat. Orang seringkali memilih produk yang menunjukkan peran dan statusnya dalam masyarakat.

\section{Faktor Pribadi}

Menurut Sumarwan (2007:47) pribadi merupakan perbedaan karakteristik yang paling dalam pada diri manusia. Perbedaan karakteristik tersebut menggambarkan ciri unik dari masingmasing individu. Karakteristik ini muncul dari dalam diri konsumen dan ada di luar Kontrol pemasar.

Keputusan membeli juga dipengaruhi oleh karakteristik pribadi, yaitu :

1) Usia dan Tahap Siklus Hidup

Seseorang membeli barang dan jasa yang berbeda selama hidupnya. Kebutuhan dan selera seseorang akan makanan, pakaian, perabot dan rekreasi juga berhubungan dengan usia. Pembelian dibentuk oleh tahap daur hidup keluarga, tahap-tahap yang mungkin dilalui oleh keluarga sesuai dengan kedewasaannya. Pemasar seringkali memberikan perhatian yang besar terhadap perubahan minat pembelian yang terjadi dan dampaknya terhadap perilaku konsumsi.

2) Pekerjaan

Pekerjaan seseorang mempengaruhi pola konsumsinya. Dengan demikian pemasar dapat mengidentifikasi kelompok yang berhubungan dengan pekerjaan yang mempunyai minat di atas rata-rata terhadap produk dan jasa mereka. Sebuah perusahaan bahkan dapat mengkhususkan produknya untuk kelompok pekerjaan tertentu.

3) Situasi ekonomi

Situasi ekonomi sekarang akan mempengaruhi pilihan produk. Pemasar produk yang peka terhadap pendapatan mengamati kecenderungan 
dalam pendapatan pribadi, tabungan dan tingkat minat. Indikator ekonomi harus diperhatikan pemasar agar dapat mengambil langkah-langkah untuk merancang ulang strategi pemasaran.

4) Gaya hidup

Gaya hidup meggambarkan perilaku seseorang, yaitu bagaimana ia hidup, menggunakan uangnya dan memanfaatkan waktu yang dimilikinya. Gaya hidup seseorang biasanya tidak permanen dan cepat berubah disesuaikan dengan perubahan hidupnya.

5) Kepribadian dan konsep diri

Kepribadian merupakan ciri bawaan psikologis manusia yang khas yang menghasilkan tanggapan yang relatif konsisten dan bertahan lama terhadap rangsangan lingkungannya. Setiap orang memiliki kepribadian yang berbeda yang dapat mempengaruhi perilaku pembeliannya. Kepribadian mengacu pada karakteristik psikologis berbeda dari seseorang yang menyebabkan tanggapan yang relatif konsisten dan bertahan lama terhadap lingkungannya. Kepribadian biasanya dijelaskan dengan sifat-sifat seperti kepercayaan diri, dominasi, otonomi, ketaatan, kemampuan bersosialisasi daya tahan dan kemampuan beradaptasi. Kepribadian sangat bermanfaat untuk menganalisis perilaku konsumen terhadap pemilihan produk atau merek tertentu.

\section{Faktor Psikologis}

Menurut Kotler dan Armstrong (2008:218) faktor psikologis sebagai bagian dari pengaruh lingkungan tempat tinggal dan hidup pada waktu sekarang tanpa mengabaikan pengaruh dimasa lampau atau antisipasinya pada waktu yang akan datang. Pilihan produk yang dibeli seseorang lebih lanjut dipengaruhi oleh faktor-faktor psikologi yang penting antara lain :

1) Motivasi

Motivasi merupakan suatu kebutuhan yang secara cukup dirangsang untuk membuat seseorang mencari kepuasan atas kebutuhannya. Seseorang memiliki banyak kebutuhan pada waktu tertentu. Beberapa kebutuhan bersifat biogenis, yaitu muncul dari tekanan biologis seperti lapar, haus, dan tidak nyaman. Kebutuhan lainnya bersifat psikogenis, yaitu mucul dari tekanan psikologis seperti kebutuhan akan pengakuan, penghargaan, atau rasa memiliki.

Menurut Engel et. al. (2006: 285): "Kebutuhan yang diaktifkan akhirnya menjadi diekspresikan dalam perilaku dan pembelian dan konsumsi dalam bentuk dua jenis manfaat yang diharapkan yaitu manfaat utilitarian, dan Manfaat hedonik/pengalaman. Manfaat utilitarian merupakan atribut produk fungsional yang obyektif. Manfaat hedonik, sebaliknya mencakup respon emosional, kesenangan panca indera, mimpi dan pertimbangan-pertimbangan estetis (Engel et. al., 2006:285).

2) Persepsi

Persepsi adalah proses dimana seseorang memilih, mengatur dan menginterpretasikan informasi untuk membentuk suatu gambaran yang berarti mengenai dunia.

Seseorang yang termotivasi siap untuk bertindak. Bagaimana seseorang yang termotivasi bertindak akan dipengaruhi oleh persepsinya terhadap situasi tertentu. Orang dapat memiliki persepsi berbeda atas objek yang sama karena tiga proses persepsi, yaitu :

a) Perhatian selektif 
Orang pada umumnya dihadapkan pada jumlah rangsangan yang sangat banyak setiap hari dan tidak semua rangsangan ini dapat diterima. Perhatian yang selektif berarti harus dapat menarik perhatian konsumen, di mana pesan yang disampaikan akan hilang bagi kebanyakan orang yang tidak berada dalam pasar untuk produk tersebut, kecuali untuk pesan yang cukup menonjol atau dominan yang mengelilingi konsumen pasar tersebut.

b) Distorsi selektif

Rangsangan yang diperhatikan konsumen juga tidak selalu seperti apa yang dimaksud. Setiap orang berusaha menyesuaikan informasi yang masuk dengan pandangannya. Distorsi selektif menggambarkan kecenderungan orang untuk meramu informasi ke dalam pengertian pribadi.

c) Ingatan selektif

Orang akan melupakan banyak hal yang mereka pelajari, namun cenderung akan mengingat informasi yang menyokong pandangan dan keyakinan mereka. Karena adanya ingatan selektif.

3) Pembelajaran

Pembelajaran merupakan perubahan pada perilaku individu yang muncul dari pengalaman. Ahli teori pembelajaran yakin bahwa pembelajaran dihasilkan melalui perpaduan kerja dorongan, rangsangan, petunjuk, tanggapan dan penguatan.

4) Keyakinan dan sikap

Melalui tindakan dan proses belajar, seseorang akan mendapatkan kepercayaan dan sikap yang mempengaruhi perilaku membeli.
Keyakinan adalah pemikiran deskriptif sesorang mengenai sesuatu. Keyakinan didasarkan pada pengetahuan pendapat atau keyakinan yang keseluruhannya mungkin mengandung faktor emosional. Sikap adalah evaluasi, perasaan dan kecenderungan seseorang terhadap suatu objek atau gagasan. Sikap menuntun orang untuk berperilaku secara relatif konsisten terhadap objek yang sama.

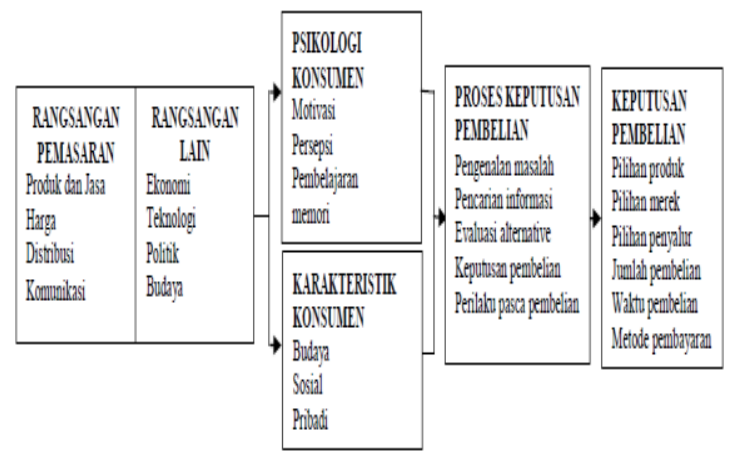

Sumber : Kotler dan Keller (2007:226)

Gambar 1 Model Perilaku Konsumen

\section{Metode Penelitian}

Populasi dan Sampel

Populasi adalah sekelompok elemen yang lengkap, yang biasanya berupa orang, objek atau kejadian dimana kita tertarik untuk mempelajari suatu objek penelitian (Kuncoro, 2009:115). Populasi dalam penelitian ini adalah konsumen yang berbelanja di Home Smart Supermarket, yang tidak bisa diketahui secara pasti jumlahnya.

Sampel adalah suatu himpunan bagian dari unit populasi (Kuncoro 2009:118). Penentuan jumlah sampel dalam penelitian ini dilakukan dengan menggunakan rumus yang dikemukakan oleh Supramono dan Haryanto (2006:62), yaitu : 
Dimana

$$
n=\frac{(Z \alpha)^{2}(P)(Q)}{\delta^{2}}
$$

$\mathrm{N}$ : Jumlah sampel

$\mathrm{Z} \alpha$ : Nilai tabel $\mathrm{Z} \alpha$ berdasarkan tingkat signifikansi tertentu

Bila $\alpha=0,05 \mathrm{Z}=1,67$, Bila $\alpha=0,01 \mathrm{Z}=$ 1,96

$\mathrm{P}$ : Estimasi proporsi populasi yang sesuai dengan kriteria sample

Q : Proporsi populasi yang tidak sesuai sample (1-p)

$\delta \quad$ : Penyimpangan yang ditolerir $(10 \%)$

Penulis memperoleh $\mathrm{n}$ (jumlah sampel) yang besar dan nilai $p$ yang belum diketahui maka dapat digunakan $\mathrm{p}$ $=0,5$. Dengan demikian, jumlah sampel yang mewakili populasi dalam penelitian ini adalah :

$$
\begin{gathered}
n=\frac{(1,96)^{2}(0,5)(0,5)}{(0,1)^{2}}=96,04 \\
=96 \text { orang }
\end{gathered}
$$

\section{Teknik Pengumpulan Data}

Adapun teknik pengumpulan data dalam penelitian ini yaitu :

1. Observasi yaitu dengan melakukan pengamatan langsung pada objek penelitian untuk mendapatkan data yang aktual.

2. Wawancara yaitu dengan melakukan tanya jawab atau wawancara secara langsung dengan pihak-pihak yang terkait dengan objek penelitian untuk mendapatkan informasi.

3. Kuesioner yaitu dengan menyebarkan daftar pertanyaan kepada sampel terpilih.

\section{Metode Analisis Data Uji Asumsi Klasik}

Sebelum data dianalisis, maka model regresi berganda harus memenuhi syarat uji asumsi klasik yang terdiri atas :
1) Uji Normalitas

Uji normalitas dilakukan untuk menguji apakah dalam model regresi, variabel bebas dan variabel terikat atau keduanya telah terdistribusi secara normal atau tidak. Model regresi yang baik adalah model yang memiliki distribusi normal atau mendekati normal. Normalitas dapat dideteksi dengan melihat penyebaran data (titik) dari sumbu diagonal dari grafik atau melihat histogram dari residualnya. Uji normalitas juga dapat dilakukan dengan menggunakan pendekatan Kolmogrov-Smirnov. Dengan menggunakan tingkat signifikansi 5\% maka jika nilai Asymp.sig (2-tailed) diatas nilai signifikansi 5\% artinya variabel residual berdistribusi normal.

2) Uji Multikoliniearitas

Uji model asumsi klasik selanjutnya adalah uji multikoliniearitas. Uji ini dilakukan untuk mengetahui apakah ada korelasi antara variabel independennya (Usman dan Sobari, 2013:75). Konsekuensi penting bagi model regresi yang mengandung multikolinieritas adalah kesalah standar estimasi akan cenderung meningkat dengan bertambahnya variabel independen, tingkat signifikansi untuk menolak hipotesis nol akan semakin besar, dan probabilitas menerima hipotesis yang salah juga akan semakin besar. Pengujian multikolniearitas dalam penelitian ini dilakukan dengan melihat nilai dari Variance Inflation Factor (VIF) dan nilai Tolerance-nya. Jika nilai VIF $<5$ dan nilai Tolerancenya > 0,1 maka tidak terjadi multikoliniearitas.

3) Uji Heteroskedastisitas

Situmorang dkk (2009:122) menyatakan bahwa uji 
heteroskedastisitas pada prinsipnya juga ingin menguji apakah sebuah grup mempunyai varians yang sama diantara anggota grup tersebut. Jika varians sama, dan ini yang seharusnya terjadi maka dikatakan ada homoskedastisitas. Sedangkan jika varians tidak sama dikatan terjadi heterokedastisitas.

\section{Analisis Regresi Linear Berganda}

Analisis regresi linear berganda digunakan untuk menganalisis seberapa besar pengaruh dan hubungan antara variabel bebas dengan variabel terikat. Analisis regresi berganda digunakan karena jumlah variabel bebas yang akan diteliti berjumlah lebih dari satu variabel. Dalam penelitian ini peneliti menggunakan aplikasi SPSS 20 for Windows untuk menghitung model regresi berganda ini. Rumus matematisnya adalah :

$\quad \mathbf{Y}=\mathbf{a}+\mathbf{b}_{\mathbf{1}} \mathbf{X}_{\mathbf{1}}+\mathbf{b}_{2} \mathbf{X}_{\mathbf{2}}+\mathbf{b}_{\mathbf{3}} \mathbf{X}_{\mathbf{3}}+$
$\mathbf{b}_{4} \mathbf{X}_{\mathbf{4}}+\boldsymbol{e}$
Dimana :
$\mathrm{Y}=$ Keputusan konsumen
$\mathrm{a}=$ Konstanta
$\mathrm{b}_{1}, \mathrm{~b}_{2}, \mathrm{~b}_{3}, \mathrm{~b}_{4}=$ Koefisien regresi
$\mathrm{X}_{1}=$ Variabel faktor budaya
$\mathrm{X}_{2}=$ Variabel faktor pribadi
$\mathrm{X}_{3}=$ Variabel faktor sosial
$\mathrm{X}_{4}=$ Variabel faktor psikologis
$e=$ Standar error

\section{Uji Hipotesis}

1) Uji Signifikansi Parsial (Uji t)

Pengujian ini dilakukan untuk mengetahui seberapa jauh pengaruh suatu variabel independen $(\mathrm{X})$ secara parsial (individual) terhadap variasi variabel dependen (Y). Bentuk pengujiannya adalah :

- $\mathrm{H}_{0}: \mathrm{bi}=0$, artinya secara parsial faktor budaya $\left(\mathrm{X}_{1}\right)$, faktor pribadi $\left(\mathrm{X}_{2}\right)$, faktor sosial $\left(\mathrm{X}_{3}\right)$, dan faktor psikologis $\left(\mathrm{X}_{4}\right)$ tidak berpengaruh signifikan terhadap keputusan konsumen berbelanja di Home Smart (Y).

- $\mathrm{H}_{\mathrm{a}}: \mathrm{bi} \neq 0$, artinya secara parsial faktor budaya $\left(\mathrm{X}_{1}\right)$, faktor pribadi $\left(\mathrm{X}_{2}\right)$, faktor sosial $\left(\mathrm{X}_{3}\right)$, dan faktor psikologis $\left(\mathrm{X}_{4}\right)$ berpengaruh signifikan terhadap keputusan konsumen berbelanja di Home Smart (Y).

Pengambilan keputusan dilakukan dengan cara membandingkan nilai $\mathrm{t}_{\text {hitung }}$ dengan $\mathrm{t}_{\text {tabel }}$ dengan kriteria :

- $\mathrm{H}_{0}$ diterima apabila nilai $\mathrm{t}_{\text {hitung }}<\mathrm{t}_{\text {tabel }}$ pada $\alpha=5 \%$.

- $\mathrm{H}_{\mathrm{a}}$ diterima apabila nilai $\mathrm{t}_{\text {hitung }}>\mathrm{t}_{\text {tabel }}$ pada $\alpha=5 \%$.

2) Uji Signifikansi Simultan (Uji F) Pengujian ini dilakukan untuk melihat apakah semua variabel independen $\left(\mathrm{X}_{1}, \mathrm{X}_{2}, \mathrm{X}_{3}, \mathrm{X}_{4}\right)$ yang dimasukkan dalam model mempunyai pengaruh secara bersama-sama terhadap variabel dependen (Y). Bentuk pengujiannya adalah :

- $\mathrm{H}_{0}: \mathrm{b}_{1}=\mathrm{b}_{2}=\mathrm{b}_{3}=\mathrm{b}_{4}=0$, artinya secara serempak faktor budaya $\left(\mathrm{X}_{1}\right)$, faktor pribadi $\left(\mathrm{X}_{2}\right)$, faktor sosial $\left(\mathrm{X}_{3}\right)$, dan faktor psikologis $\left(\mathrm{X}_{4}\right)$ tidak berpengaruh signifikan terhadap keputusan konsumen berbelanja di Home Smart (Y).

- Ha: $b_{1} \neq b_{2} \neq b_{3} \neq b_{4}=0$, artinya secara serempak faktor budaya $\left(\mathrm{X}_{1}\right)$, faktor pribadi $\left(\mathrm{X}_{2}\right)$, faktor sosial $\left(\mathrm{X}_{3}\right)$, dan faktor psikologis $\left(\mathrm{X}_{4}\right)$ berpengaruh signifikan terhadap keputusan konsumen berbelanja di Home Smart (Y).

Pengambilan keputusan dilakukan dengan cara membandingkan nilai $\mathrm{F}_{\text {hitung }}$ dengan $\mathrm{F}_{\text {tabel }}$ dengan kriteria :

- $\mathrm{H}_{0}$ diterima apabila nilai $\mathrm{F}_{\text {hitung }}<\mathrm{F}_{\text {tabel }}$, pada $\alpha=5 \%$.

- $\mathrm{H}_{\mathrm{a}}$ diterima apabila nilai $\mathrm{F}_{\text {hitung }}>\mathrm{F}_{\text {tabel }}$, pada $\alpha=5 \%$. 
3) Koefisien Determinasi $\left(R^{2}\right)$

Determinan digunakan untuk melihat seberapa besar pengaruh variabel bebas terhadap variabel terikat, dengan kata lain Koefisien Determinan digunakan untuk mengukur besarnya variabel bebas $(\mathrm{X})$ yang diteliti yaitu berupa faktor budaya, faktor pribadi, faktor sosial, dan faktor psikologis tehadap variabel terikat (Y) yaitu kepuasan nasabah. Koefisien Determinasi $\left(R^{2}\right)$ berkisar antara Nol sampai dengan $1\left(0 \leq R^{2} \leq 1\right)$, hal ini berarti bila $R^{2}=0$ menunjukkan tidak adanya pengaruh variabel bebas pada variabel terikat dan bila $R^{2}$ mendekati 1 maka menunjukkan semakin kuatnya pengaruh variabel bebas kepada vaiabel terikat.

\section{Hasil Dan Pembahasan Hasil Uji Asumsi Klasik Uji Normalitas}

Uji normalitas ini dilakukan untuk mengetahui apakah variabel dependen, independen, atau keduanya berdistribusi normal, mendekati normal, atau tidak. Ada dua cara untuk mendeteksi apakah residual berdistribusi normal atau tidak yaitu dengan analisis grafik dan uji statistik.

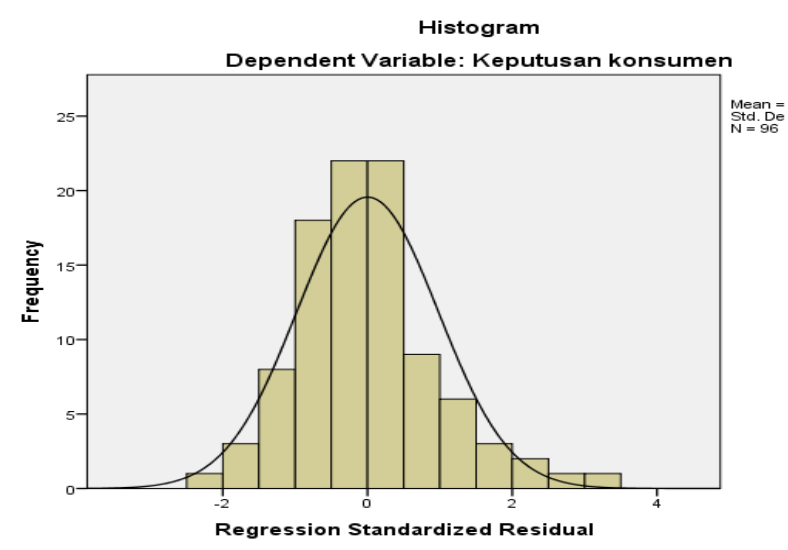

Gambar 2 Histogram
Berdasarkan Gambar 2, dapat dilihat bahwa variabel berdistribusi normal, hal ini ditunjukkan oleh distribusi data tersebut tidak menceng ke kiri atau menceng ke kanan.

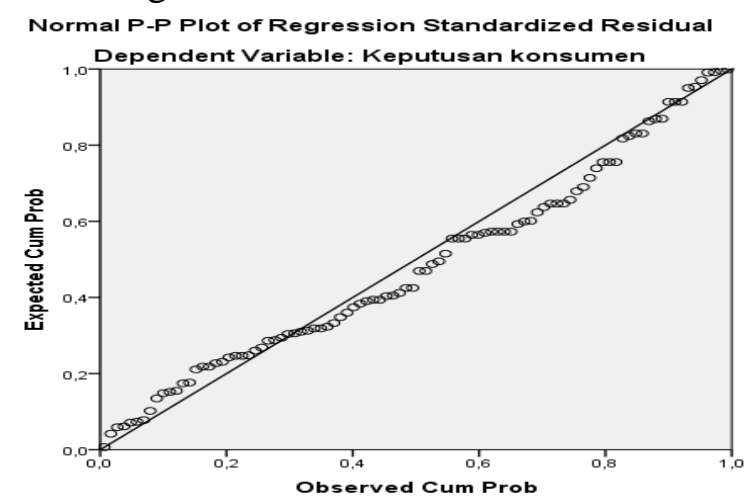

Gambar 3 Normal PP Plot

Pada Gambar 3 grafik normal $P P$ Plot terlihat titik-titiknya menyebar disekitar garis diagonal, serta penyebarannya mengikuti arah garis diagonal. Hal ini berarti data berdistribusi normal.

Tabel 1

Hasil Uji Kolmogorov-Smirnov

One-Sample Kolmogorov-Smirnov Test

\begin{tabular}{|c|c|c|}
\hline & & $\begin{array}{c}\text { Unstandardized } \\
\text { Residual }\end{array}$ \\
\hline $\begin{array}{l}\text { N } \\
\text { Normal Parameters". } \\
\text { Most Exteme Diferences } \\
\text { Kolmogorov-Smirnov Z } \\
\text { Asymp. Sig. (2-tailed) }\end{array}$ & $\begin{array}{l}\text { Nean } \\
\text { Std. Deviation } \\
\text { Absolute } \\
\text { Posifie } \\
\text { Negafive }\end{array}$ & $\begin{array}{r}96 \\
0 E-7 \\
1,01800837 \\
, 090 \\
, 090 \\
-, 060 \\
, 885 \\
, 413\end{array}$ \\
\hline
\end{tabular}

Pada Tabel 1 terlihat bahwa nilai Asymp.Sig. (2-tailed) adalah 0,413, nilai tersebut berada di atas nilai signifikan $(0,05)$. Hal ini berarti variabel residual berdistribusi normal. 


\section{Uji Multikolinearitas}

Tabel 2

\section{Hasil Uji Multikolinearitas}

\begin{tabular}{|c|c|c|c|c|c|c|c|}
\hline \multicolumn{8}{|c|}{ Coefficients" } \\
\hline \multirow[t]{2}{*}{ |lodel } & \multicolumn{3}{|c|}{\begin{tabular}{|r} 
Unstandardized Coeficients Standardiad \\
Coeficents
\end{tabular}} & \multirow[t]{2}{*}{$t$} & \multirow[t]{2}{*}{$S_{g}}$. & \multicolumn{2}{|c|}{ Collinearity Statisics } \\
\hline & $B$ & St. Error & Beta & & & Tolerance & $V \mid F$ \\
\hline (Constant) & $.1,840$ & 1952 & & .948 & 347 & & \\
\hline Budjya &., 476 & 12 & 348 & 3,887 &, 000 & .883 & 1,484 \\
\hline 1 Pribadi & .458 &, 118 & 310 & 3,854 & .000 & 845 & 1,183 \\
\hline Sosial &, 278 & 138 & 183 & 2,028 & .045 & 874 & 1,484 \\
\hline Pgilologis & 222 & 100 & 102 & 2,099 & .039 & .920 & 1,087 \\
\hline
\end{tabular}

Pada Tabel 2 dapat dilihat bahwa semua variabel independen (faktor budaya, pribadi, sosial, dan psikologis) mempunyai nilai VIF $<5$ dan tolerance $>$ 0,1 . Sehingga data tidak mengalami gejala multikolinearias.

\section{Uji Heteroskedostisitas}

Scatterplot

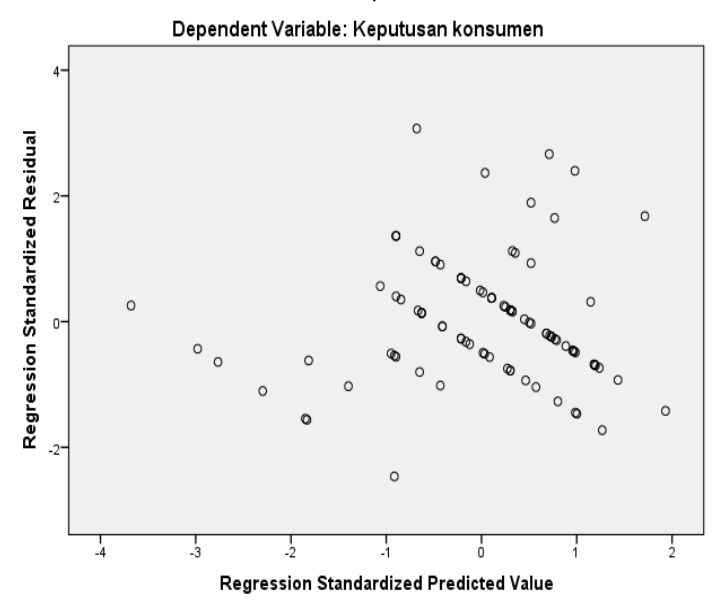

Gambar 4 Scatterplot

Berdasarkan Gambar 4 dapat dilihat bahwa pada tampilan grafik scatterplot, titik-titik menyebar secara acak baik di atas maupun di bawah angka 0 pada sumbu Y. dengan demikian, dapat disimpulkan bahwa tidak terjadi heteroskedastisitas pada model regresi.
Tabel 3

Hasil Uji Glejser

Coefficients"

\begin{tabular}{|c|c|c|c|c|c|c|}
\hline \multirow[t]{2}{*}{ Mod } & & \multicolumn{2}{|c|}{ Unstandardized Coeficients } & \multirow{2}{*}{$\begin{array}{c}\begin{array}{c}\text { Stand ardized } \\
\text { Coeficients }\end{array} \\
\text { Beta } \\
\end{array}$} & \multirow[t]{2}{*}{$t$} & \multirow[t]{2}{*}{ Sig. } \\
\hline & & $B$ & Stl. Error & & & \\
\hline \multirow{5}{*}{1} & (Constant) & 1,781 & 1,198 & & 1,477 &, 143 \\
\hline & Budaja & ,094 &, 075 & 150 & 1,244 & .217 \\
\hline & Pribadi & .128 & .073 & 191 & 1,785 & .081 \\
\hline & Sosial & -104 &, 083 & - 152 & $-1,253$ & .213 \\
\hline & Psikologis & . 165 & .085 & .285 & .2554 & .072 \\
\hline
\end{tabular}

Berdasarkan Tabel di atas, diperoleh nilai signifikansi variabel faktor budaya, pribadi, sosial, dan psikologis lebih besar dari tingkat signifikansi 0,05. Dengan demikian dapat disimpulkan tidak terjadi gejala heteroskedastisitas dalam model regresi ini.

\section{Analisis Regresi Linear Berganda}

Tabel 4

Hasil Regresi Linear Berganda Coefficients"

\begin{tabular}{|c|c|c|c|c|c|c|}
\hline \multirow[t]{2}{*}{ Mode } & & \multicolumn{2}{|c|}{ Unstandardized Coeficients } & \multirow{2}{*}{$\begin{array}{c}\begin{array}{c}\text { Sendadized } \\
\text { Coeficients }\end{array} \\
\text { Beta } \\
\end{array}$} & \multirow[t]{2}{*}{$t$} & \multirow[t]{2}{*}{ Sig. } \\
\hline & & $B$ & St, Error & & & \\
\hline \multirow{5}{*}{1} & (Constant) & $.1,848$ & 1,952 & & .948 &, 347 \\
\hline & Budaja & .478 & , 123 & 348 & 3,887 &, 000 \\
\hline & Pribadi &, 468 & , 119 & 310 & 3,854 &, 000 \\
\hline & Sosial & .278 &, 138 & , 183 & 2,028 & .045 \\
\hline & Psikologis & 223 &, 108 & 102 & 2,099 &, 039 \\
\hline
\end{tabular}

Berdasarkan Tabel 4 pada kolom Unstandardized Coefficients bagian B adalah nilai koefien regresi masingmasing variabel. Maka regresi linier berganda dirumuskan sebagai berikut :

$\mathrm{Y}=-1,846+0,476 \mathrm{X}_{1}+0,458 \mathrm{X}_{2}+$ $0,276 \mathrm{X}_{3}+0,223 \mathrm{X}_{4}+e$

Interpretasi persamaan tersebut adalah sebagai berikut :

1) Konstanta sebesar $\quad-1,846$ menunjukkan bahwa jika variabel independen faktor budaya $\left(\mathrm{X}_{1}\right)$, faktor pribadi $\left(\mathrm{X}_{2}\right)$, faktor sosial $\left(\mathrm{X}_{3}\right)$, dan faktor psikologis $\left(\mathrm{X}_{4}\right)$ tidak ada 
(bernilai nol), maka keputusan konsumen untuk berbelanja di Home Smart (Y) turun sebesar 1,846.

2) Koefisien regresi $\left(b_{1}\right)$ untuk variabel faktor budaya $\left(\mathrm{X}_{1}\right)$ sebesar 0,476 menunjukkan bahwa setiap kenaikan faktor budaya sebesar 1 satuan dan variabel lain tetap (variabel lain sama dengan nol), maka keputusan konsumen untuk berbelanja di Home Smart akan meningkat sebesar 0,476.

3) Koefisien regresi $\left(b_{2}\right)$ untuk variabel faktor pribadi $\left(\mathrm{X}_{2}\right)$ sebesar 0,458 menunjukkan bahwa setiap kenaikan nilai faktor pribadi sebesar 1 satuan dan variabel lain tetap (variabel lain sama dengan nol), maka keputusan konsumen untuk berbelanja di Home Smart akan meningkat sebesar 0,458.

4) Koefisien regresi $\left(b_{3}\right)$ untuk variabel faktor sosial $\left(\mathrm{X}_{3}\right)$ sebesar 0,276 menunjukkan bahwa setiap kenaikan faktor sosial sebesar 1 satuan dan variabel lain tetap (variabel lain sama dengan nol), maka keputusan konsumen untuk berbelanja di Home Smart akan meningkat sebesar 0,276.

5) Koefisien regresi $\left(b_{4}\right)$ untuk variabel faktor psikologis $\left(\mathrm{X}_{4}\right)$ sebesar 0,223 menunjukkan bahwa setiap kenaikan faktor psikologis sebesar 1 satuan dan variabel lain tetap (variabel lain sama dengan nol), maka keputusan konsumen untuk berbelanja di Home Smart akan meningkat sebesar 0,223.

\section{Pengujian Hipotesis}

Uji Signifikansi Parsial (Uji t)

Tabel 5

\section{Hasil Uji t}

\begin{tabular}{|c|c|c|c|c|c|c|}
\hline \multirow{3}{*}{ Model } & & \multicolumn{3}{|c|}{ Coefficients" } & \multirow{3}{*}{$t$} & \multirow{3}{*}{ Sig. } \\
\hline & & \multicolumn{2}{|c|}{ Unstandardized Coeficients } & $\begin{array}{l}\text { Stand ardized } \\
\text { Coefficients }\end{array}$ & & \\
\hline & & $B$ & St. Error & Beta & & \\
\hline \multirow{5}{*}{1} & (Constent) & $-1,848$ & 1,952 & & -946 & .347 \\
\hline & Budaya & .476 & .123 & 348 & 3,887 & .000 \\
\hline & Pribadi & .458 & .119 & 310 & 3,854 & .000 \\
\hline & Sosial & .276 & .138 & 183 & 2,028 & .045 \\
\hline & Psikologis & 223 & , 108 & 162 & 2,099 & .039 \\
\hline
\end{tabular}

Pada Tabel 5 Uji $\mathrm{t}$ memperlihatkan bahwa :

1) Variabel faktor budaya $\left(X_{1}\right)$ memiliki nilai $\mathrm{t}_{\text {hitung }}(3,867)>\mathrm{t}_{\text {tabel }}(1,662)$ dan nilai signifikansi $(0,000)<(0,05)$, maka dapat disimpulkan Ha diterima (Ho ditolak), artinya faktor budaya secara parsial berpengaruh positif dan signifikan terhadap keputusan konsumen untuk berbelanja di Home Smart.

2) Variabel faktor pribadi $\left(X_{2}\right)$ memiliki nilai $\mathrm{t}_{\text {hitung }}(3,854)>\mathrm{t}_{\text {tabel }}(1,662)$ dan nilai signifikansi $(0,000)<(0,05)$, maka dapat disimpulkan Ha diterima (Ho ditolak), artinya faktor pribadi secara parsial berpengaruh positif dan signifikan terhadap keputusan konsumen untuk berbelanja di Home Smart.

3) Variabel faktor sosial $\left(X_{3}\right)$ memiliki nilai $t_{\text {hitung }}(2,028)>t_{\text {tabel }}(1,662)$ dan nilai signifikansi $(0,045)<(0,05)$, maka dapat disimpulkan Ha diterima (Ho ditolak), artinya faktor sosial secara parsial berpengaruh positif dan signifikan terhadap keputusan konsumen untuk berbelanja di Home Smart.

4) Variabel faktor psikologis $\left(X_{4}\right)$ memiliki nilai $t_{\text {hitung }}(2,099)>t_{\text {tabel }}$ $(1,662)$ dan nilai signifikansi $(0,039)<$ $(0,05)$, maka dapat disimpulkan diterima (Ho ditolak), artinya faktor psikologis secara parsial berpengaruh positif dan signifikan terhadap keputusan konsumen untuk berbelanja di Home Smart. 


\section{Uji Signifikansi Simultan (Uji F) \\ Tabel 6 Hasil Uji F}

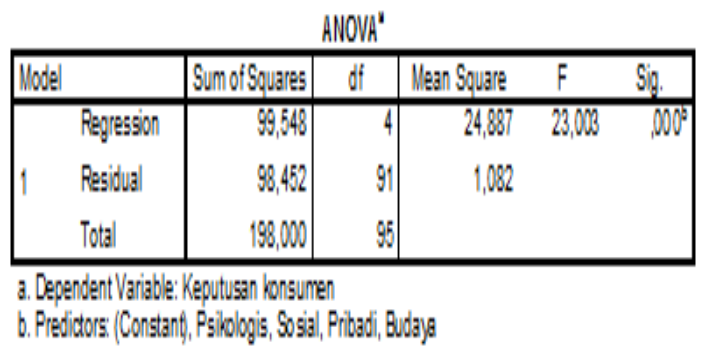

Berdasarkan Tabel diatas memperlihatkan bahwa nilai $F_{\text {hitung }}$ $(23,003)>F_{\text {tabel }}(2,47)$ dan nilai signifikan $0,000<0,05$ sehingga dapat disimpulkan Ho ditolak (Ha diterima). Artinya faktor budaya, faktor pribadi, faktor sosial, dan faktor psikologis secara bersama-sama berpengaruh berpengaruh positif dan signifikan terhadap variabel dependen yaitu keputusan konsumen untuk berbelanja di Home Smart.

\section{Koefisien Determinasi $\left(\boldsymbol{R}^{2}\right)$}

Tabel 7

Koefisien Determinasi

Nodel Summary

\begin{tabular}{|l|c|r|r|c|}
\hline Model & $R$ & R. Square & $\begin{array}{c}\text { Adjusted R } \\
\text { Square }\end{array}$ & $\begin{array}{c}\text { Stl Error of the } \\
\text { Estimate }\end{array}$ \\
\hline 1 &, 709 &, 003 &, 481 & 1,040 \\
\hline
\end{tabular}

Berdasarkan Tabel 7 dapat dilihat bahwa nilai $R$ sebesar 0,709 yang berarti bahwa hubungan antara faktor budaya, faktor pribadi, faktor sosial, dan faktor psikologis adalah kuat. Nilai $R$ Square dalam penelitian ini yaitu sebesar 0,503 yang berarti $50,3 \%$ keputusan konsumen untuk berbelanja di Home Smart dapat dijelaskan oleh faktor budaya, faktor pribadi, faktor sosial, dan faktor psikologis, sedangkan sisanya $49,7 \%$ dijelaskan oleh variabel lain yang tidak diteliti dalam penelitian ini.
Standard Error of Estimated artinya mengukur variabel dari nilai yang diprediksi. Standard Error of Estimated disebut juga standar deviasi. Standard Error of Estimated dalam penelitian ini adalah 1,040. Semakin kecil standar deviasi berarti model semakin baik.

\section{Pembahasan}

Sebuah perusahaan yang baik adalah perusahaan yang memperhatikan apa yang dibutuhkan oleh konsumennya. Perilaku konsumen yang terus menerus berubah membuat perusahaan harus terus belajar memperbaiki strategi pemasaran dan kinerja perusahaan. Bagi perusahaan, strategi pemasaran yang tepat dapat mendorong dan mempengaruhi konsumen melakukan pembelian.

Sebagai salah satu perusahaan yang bergerak di bidang ritel bahan bangunan dan elektrikal telah membuktikan bagaimana pengetahuan tentang perilaku konsumen dan strategi pemasaran yang tepat mampu mengembangkan sebuah sebuah perusahaan lokal menjadi perusahaan berskala nasional seperti sekarang ini. Dengan adanya pengetahuan akan perilaku konsumen, perusahaan akan mampu melihat peluang pasar di daerah lain termasuk di daerah Kabupaten Labuhanbatu. Perilaku konsumen di tiap daerah pasti berbeda-beda, hal ini disebabkan oleh perbedaan budaya dan kebiasaan yang ada di dalam masyarakat itu sendiri.

Berdasarkan hasil penelitian, bahwa secara parsial variabel faktor budaya, pribadi, sosial, dan psikologis berpengaruh positif dan signifikan terhadap keputusan konsumen untuk berbelanja di Home Smart. Faktor budaya dan pribadi adalah faktor yang paling dominan mempengaruhi keputusan 
konsumen. Kedua perilaku konsumen ini paling sering berubah-ubah dari waktu ke waktu mengikuti perkembangan zaman dan keinginan konsumen itu sendiri. Apabila perusahaan tidak mampu melihat kecenderungan pasar, maka akan semakin tertinggal dari perusahaan lain yang sejenis. Itulah alasannya mengapa diperlukan pemahaman dan pembelajaran tentang perilaku konsumen. Hasil peneitian juga menunjukkan bahwa secara simultan faktor budaya, pribadi, sosial, dan psikologis berpengaruh positif dan signifikan terhadap keputusan konsumen untuk berbelanja di Home Smart. keputusan konsumen untuk berbelanja di Home Smart dapat dijelaskan oleh faktor budaya, faktor pribadi, faktor sosial, dan faktor psikologis sebesar 50,3\%, sedangkan sisanya $49,7 \%$ dijelaskan oleh variabel lain yang tidak diteliti dalam penelitian ini, misalnya : merek, image, harga, promosi, dan lain sebagainya.

\section{Kesimpulan Dan Saran \\ Kesimpulan}

Berdasarkan hasil penelitian, maka dapat diambil kesimpulan sebagai berikut :

1. Secara parsial, faktor budaya berpengaruh positif dan signifikan terhadap keputusan konsumen untuk berbelanja di Home Smart.

2. Secara parsial, faktor pribadi berpengaruh positif dan signifikan terhadap keputusan konsumen untuk berbelanja di Home Smart.

3. Secara parsial, faktor sosial berpengaruh positif dan signifikan terhadap keputusan konsumen untuk berbelanja di Home Smart.

4. Secara parsial, faktor psikologis berpengaruh positif dan signifikan terhadap keputusan konsumen untuk berbelanja di Home Smart.

5. Secara simultan, faktor budaya, faktor pribadi, faktor sosial, dan faktor psikologis berpengaruh positif dan signifikan terhadap keputusan konsumen untuk berbelanja di Home Smart.

6. Keputusan konsumen dapat dijelaskan oleh faktor budaya, pribadi, sosial, dan psikologis sebesar 50,3\%, sedangkan sisanya $49,7 \%$ dijelaskan oleh variabel lain yang tidak diteliti dalam penelitian ini, misalnya : merek, image, harga, promosi, dan lain sebagainya.

\section{Saran}

Berdasarkan kesimpulan di atas, maka peneliti memberikan saran sebagai berikut :

1. Hasil penelitian menyatakan bahwa variabel faktor budaya dan pribadi lebih dominan mempengaruhi keputusan konsumen untuk berbelanja di Home Smart, maka perusahaan Home Smart diharapkan terus memperhatikan dan mempelajari sisi pribadi konsumen yang cenderung berubah-ubah agar dapat terus memberikan pelayanan yang terbaik bagi para konsumen.

2. Penelitian ini menggunakan empat variabel bebas untuk mengukur keputusan konsumen, oleh karena itu bagi peneliti selanjutnya diharapkan memperhatikan variabel bebas tersebut dengan mengembangkan indikatorindikator yang lebih tepat ataupun menambahkan variabel lainnya yang dapat mengukur keputusan pembelian konsumen.

\section{Daftar Pustaka}

Damanik, Berdian. 2008. "Analisis Faktor Pribadi dan Faktor Psikologis Terhadap Proses 
Keputusan Konsumen Pada Gamestation Jl. DjaminGinting Padang Bulan Medan". Skripsi. Fakultas Ekonomi. Medan : USU.

Engel, James F. Roger D. Blackwell dan Paul W Miniard. 2006. Perilaku Konsumen (Alih Bahasa Budi Janto), Jilid I, Edisi Keenam. Jakarta : Binarupa Aksara.

Ferrinadewi, Erna. 2008, Merek dan Psikologi Konsumen. Edisi Pertama. Yogyakarta : Graha Ilmu.

Ghozali, Imam. 2007. Aplikasi Analisis Multivariate dengan Program SPSS. Semarang : Badan Penerbit Universitas Diponegoro.

Kotler, Philips dan Keller. 2007. Manajemen Pemasaran. Jilid I, Edisi kedua belas. Jakarta : Indeks.

Kotler, Philips dan Gery Armstrong. 2008. Prinsip-prinsip Pemasaran. Jilid I, Edisi kedelapan. Jakarta : Erlangga.

Kuncoro, Mudrajad. 2009. Metode Riset untuk Bisnis \& Ekonomi (Edisi 3). Jakarta : Erlangga.

Mowen, Jhon dan Minor. 2007. Perilaku Konsumen. Jakarta : Erlangga.

Nasution, Rizki Affandy. 2010. “Analisis Faktor-Faktor Yang Mempengaruhi Konsumen Dalam Pengambilan Keputusan Pembelian Produk Mie Instan Merek Sedaap Pada Mahasiswa Fakultas Ekonomi Program Ekstensi Universitas Sumatera Utara". Skripsi. Medan : Universitas Sumatera Utara.

Prayoga, Putra Saguh. 2009. "Pengaruh Faktor Budaya, Sosial, Pribadi, Dan Psikologis Terhadap Pengambilan Keputusan Pembelian Mie Instan Merek
Sedaap (Studi Kasus Mahasiswa Yang Kost Di Lingkungan Kampus USU)". Jurnal, Fakultas Ekonomi. Medan : Universitas Sumatera Utara.

Rosidi, Purwaningsih dkk. 2010. Impulsive Buying. Semarang : Universitas Negeri Semarang.

Setiadi, Nugroho J. 2008. Perilaku Konsumen. Jakarta : Prenada Media Group.

Situmorang, Syafrizal Helmi dan Ginting, Paham. 2009. Analisis Data Penelitian. Cetakan Kedua. Medan : USU Press.

Sumarwan, Ujang. 2007. Perilaku Konsumen : Teori dan Penerapannya Dalam Pemasaran. Cetakan kedua. Bogor : Ghalia Indonesia.

Supramono dan Haryanto. 2006. Desain Proposal Penelitian Studi Pemasaran. Yogyakarta : Andi.

Tjiptono, Fandy. 2006. Pemasaran Jasa. Edisi I. Malang : Bayumedia Pubishing.

Umar, Husein. 2006. Riset Pemasaran dan Perilaku Konsemen. Jakarta : Gramedia Pustaka Utama.

Usman, Hardius dan Nurdin Sobari. 2013. Aplikasi Teknik Multivariate untuk Riset Pemasaran. Jakarta : PT. Raja Grafindo Persada. 